Discussion Paper No. 01-42

\title{
Accounting for Stock-Based Compensation: An Extended Clean Surplus Relation
}

\author{
Dirk Hess and Erik Lüders
}

Download this ZEW Discussion Papers from our ftp server:

ftp://ftp.zew.de/pub/zew-docs/dp/dp0142.pdf

Die Discussion Papers dienen einer möglichst schnellen Verbreitung von neueren Forschungsarbeiten des ZEW. Die Beiträge liegen in alleiniger Verantwortung der Autoren und stellen nicht notwendigerweise die Meinung des ZEW dar.

Discussion Papers are intended to make results of ZEW research promptly available to other economists in order to encourage discussion and suggestions for revisions. The authors are solely responsible for the contents which do not necessarily represent the opinion of the ZEW. 


\section{Non-Technical Summary}

Employee stock option plans are becoming more and more a substantial part of compensation schemes, not only in the U.S. but also in Germany. One reason is that options are commonly seen as an appropriate instrument to resolve principal agent problems since they may align employees' and shareholders' interests. In addition, these programs allow companies applying U.S. accounting rules to hide a substantial part of compensation cost.

Several problems for the valuation of companies arise from the current accounting practice of footnote disclosure of stock-based compensation cost. Applying traditional valuation models leads to a significant over-estimation of fundamental stock values. This is due to the fact that at least two key assumptions are violated. First, reported earnings of companies granting stock options can be substantially overstated. Second, traditional valuation models assume that the payment stream belongs to current shareholders only. However, employee options create additional potential shareholders.

This paper presents a new valuation model which explicitly accounts for the aforementioned problems. Since the derived valuation formula allows to estimate the fundamental value of stocks based exclusively on current accounting information, the model can be easily implemented. As a major advantage, our model allows a comparison of 'new-economy' companies which rely heavily on stock options and more traditional companies with less distorted stated earnings. 


\title{
Accounting for stock-based compensation: an extended clean surplus relation
}

\author{
Dieter Hess*and Erik Lüders ${ }^{\dagger}$
}

June 2001

\begin{abstract}
Residual income valuation is based on the assumption that the clean surplus relation holds. As pointed out by Ohlson (2000), among others, the standard clean surplus relation is frequently violated. Moreover, standard residual income valuation models rest on the implicit assumption that future stated earnings belong to current shareholders only. This is clearly invalid for companies granting employee options. In order to overcome these deficiencies, this paper establishes an extension of the clean surplus relation and derives simple analytical solutions for the value of outstanding stocks in terms of already known accounting information.
\end{abstract}

JEL classification: M 41, G 12

Keywords: Residual income valuation; clean surplus accounting;

US-GAAP; employee stock option programs

\footnotetext{
${ }^{*}$ Center of Finance and Econometrics (CoFE), University of Konstanz, D-78457 Konstanz, Germany, e-mail: dieter.hess@uni-konstanz.de

${ }^{\dagger}$ Centre for European Economic Research (ZEW), D-68161 Mannheim, Germany, and Center of Finance and Econometrics (CoFE), University of Konstanz, D-78457 Konstanz, Germany, e-mail: lueders@zew.de
} 


\section{Introduction}

This paper analyzes the link between accounting information and stock prices on the basis of an extended residual income valuation model in the spirit of Ohlson (1995). Since stock-based compensation has become increasingly popular, especially with so-called new-economy companies, this paper presents two extensions of previous residual income valuation models in order to carve out the value impact of this new trend in employee compensation. First, by augmenting the standard clean surplus relation with value relevant items, a simple analytical solution for the present value of future distributions to stakeholders in terms of accounting information is obtained. Second, by applying straightforward value-additivity arguments a rule for sharing this present value among holders of stocks and options is derived, and thus a formula for valuing stocks in the presence of employee options. Focusing on US Generally Accepted Accounting Rules (US-GAAP), our model has implications for the valuation of companies outside the US as well. German companies, for example, can elect US-GAAP in order to report consolidated operations. ${ }^{1}$

Residual income valuation derives the fair value of stocks in terms of accounting information, in particular, income adjusted for the cost of capital. This technique is based on the assumption that the clean surplus relation (CSR) holds. This accounting identity states that the change in book value of equity is caused solely by stated earnings and dividends. Unfortunately, the standard CSR is almost always violated (see, for example Ohlson 2000). Major neglected items are capital in- and outflows.

\footnotetext{
${ }^{1} \S 292 \mathrm{a}(2)$ HGB exempts companies from presenting consolidated statements compliant with German accounting standards if internationally accepted accounting rules are applied to report consolidated operations. Furthermore, companies at the German Neuer Markt have to present annual statements following either International Accounting Standards (IAS) or US-GAAP (section 7.3.2 FWB Rules and Regulations Neuer Markt).
} 
Another critical item arises from the treatment of stock-based compensation. Even after adjusting for capital contributions due to the exercise of stock options, the CSR does not hold because companies usually receive large tax benefits which do not pass through the profit and loss statement. ${ }^{2}$ In order to restore the viability of residual income valuation this paper provides an extension of the CSR by explicitly incorporating formerly neglected items.

Besides distorting the CSR, stock-based compensation raises another critical valuation issue. Since the residual income valuation model is derived from the well-known dividend discount model, distributions to shareholders determine the value of outstanding stocks. The main problem is that using stated earnings overestimates the stake of current shareholders in the potential distribution stream, since current USGAAP allow companies to hide a substantial part of stock-based compensation cost. The Financial Accounting Standards Board's Statement No. 123 (SFAS 123) "encourages" all entities to measure the wage component provided by options applying the so-called "fair value method". Nevertheless, it allows companies to continue recognizing compensation cost by the "intrinsic value method" of Accounting Principal Board Opinion No. 25 (APB 25). In other words, while SFAS 123 suggests to recognize the full option value at grant according to an appropriate option pricing model, APB 25 only requires to recognize the amount by which the stock price at grant exceeds the exercise price, and thus, allows to ignore the time value of options.

As a consequence, hidden compensation cost can reach substantial amounts since both, the number of granted options as well as their time value are by no means

\footnotetext{
${ }^{2}$ For example, in fiscal 2000 Cisco received a tax benefit of nearly $\$ 3.08$ billion which compares to a stated profit of $\$ 2.67$ billion. In addition, the book value of equity increased by nearly $\$ 1.56$ billion due to the increase of common stock issued into stock option and stock purchase programs.
} 
negligible. Most stock options are granted at-the-money with a life of up to ten years (see e.g. NCEO 2000), resulting in non-expensed time values which frequently exceed $25 \%$ of current share prices. Evidence for the strongly increasing number of stock option grants is provided, for example, by Core, Guay, and Kothari (2000) who find that the median number of shares reserved for stock options increased from $4.6 \%$ of outstanding shares in 1985 to $8.9 \%$ in 1995. ${ }^{3}$ The National Center for Employee Ownership (NCEO 2000) estimates that seven to ten million employees receive stock options as of May 2000, up from around 1 million in $1991 .^{4}$ Since most companies opt for footnote disclosure, reported earnings can be way overstated. ${ }^{5}$ For example, Hess and Lüders (2001) document that average stated earnings of NASDAQ 100 companies in fiscal 1999 would have been reduced by more than $20 \%$ if companies had applied the fair-value method. ${ }^{6}$

Interestingly, after the FASB announced that it would mandate stock option expensing, it was confronted with immense lobbying. ${ }^{7}$ Although the "Board continues to believe that financial statements would be more relevant and representationally faithful if the estimated fair value of employee stock options was included in deter-

\footnotetext{
${ }^{3}$ See also Core and Guay (2000) who state: "In some companies stock options are used so extensively that institutional shareholders have begun recently to refuse approving increases in the number of shares available for options.".

${ }^{4}$ Evidence for the overboarding use of stock options is also provided, for example, by Carson (2000), Towers Perrin (2000), and Callies and Sareen (2000).

${ }^{5}$ See, for example, Hess and Lüders (2001) who find that only one company out of the NASDAQ 100 index applies the fair value method in the financial year 1999 .

${ }^{6}$ On the basis of option grants for $144 \mathrm{~S} \& \mathrm{P}$ companies, a study conducted by Federal Reserve economists estimates that stated earnings would have been $10.5 \%$ lower (see Liang and Sharpe 1999). Investigating 'America's biggest companies', Smithers \& Co. find even larger numbers (see "Called to account", Economist, January 27, 2001).

${ }^{7}$ See, for example, Dechow et al (1996), Freeman and Larsen Jr. (2000), or Street et al (1997) for a detailed description and analysis of lobbying activities. Dechow et al investigate the characteristics of firms submitting comment letters lobbying against mandatory stock option expensing. They find that top-executives in these firms receive a greater proportion of their compensation from stock options, as compared to their peers in the same industries.
} 
mining an entity's net income, just as all other forms of compensation are included", 8 it nevertheless decided not to mandate a charge to earnings. A major reason may be that "the nature of the debate threatened the future of accounting standards setting in the private sector." 9

Yet, only a few studies address the question whether investors are aware of stock options. Moreover, their results are contradictory. For example, Aboody (1996) finds a negative relation between stock prices and the estimated value of outstanding employee options. In contrast, Rees and Stott (1998) find a positive relation between stock returns and stock options expense disclosed in the footnotes for fiscal year 1996. The inconsistency of these results may be due to the fact that they are based on ad-hoc regression specifications, related only loosely to residual income valuation. ${ }^{10}$ Moreover, the empirical assessment of fundamental value based on standard residual income valuation models has to be interpreted very carefully, especially when companies significantly substitute ordinary wage components by employee stock option grants. ${ }^{11}$

The extended valuation model presented in this paper points out an avenue for further empirical research by giving rise to some immediately testable implications. In particular, our model permits to estimate and test whether stock prices are driven by fundamentals, controlling explicitly for stock option cost. It is also possible to test

\footnotetext{
${ }^{8}$ Financial Accounting Standard Board Statement No. 123, paragraph 61, final version October 1995.

${ }^{9}$ Financial Accounting Standard Board Statement No. 123, paragraph 59, final version October 1995.

${ }^{10}$ For an overview of regression specifications used in the context of fundamental asset pricing see, for example, Dechow et al (1999).

${ }^{11}$ For applications of the model established by Ohlson (1995) and Feltham, Ohlson (1995, 1999) based on the standard CSR see, for example, Dechow, Hutton, and Sloan (1999), Liu and Ohlson (2000), Tse and Yaansah (1999), Sougiannis and Yaekura (2000).
} 
whether the established sharing rule for the value of expected distributions to holders of shares and options is violated. Thus, the model gives rise to some straightforward tests of whether investors are aware of hidden stock-based compensation cost. ${ }^{12}$ This could provide a better understanding why so many companies opt for footnote disclosure of stock-based compensation in order to avoid a charge to earnings.

The paper is organized as follows. Section 2 discusses value relevant items to be included into the standard clean surplus relation and delineates residual income valuation on the basis of an extended clean surplus relation. In section 3, the impact of stock-based compensation on the valuation of stocks is analyzed. In particular, the distribution of value between current shareholders and option holders is derived based on straightforward no-arbitrage arguments. Section 4 derives an expression in terms of already known accounting data employing the earnings dynamics introduced by Ohlson (1995). Section 5 concludes.

\footnotetext{
${ }^{12}$ This aspect of informational efficiency has been questioned, recently. For example, Hess and Lüders (2000) argue that companies might successfully exploit accounting rules for employee options (see also Franke 2000 and Adam-Müller and Wangler 2001). This is in line with the findings of Yermack (1998) that companies play down the value of CEO options. He suspects that companies might also try to curb disclosed employee compensation.
} 


\section{An extended clean surplus relation}

The standard clean surplus relation requires that the book value of equity, $B_{t}$, at the end of period $t$ differs from the previous period's book value only by period $t$ 's earnings $X_{t}$ and dividends $D_{t}$ (see e.g. Lücke 1955 or Ohlson 1995):

$$
B_{t}=B_{t-1}+X_{t}-D_{t}
$$

This relation assumes that all items, besides dividends, which affect the book value of equity must pass through the profit and loss statement. However, this relation rarely holds since the statement of shareholders' equity contains a variety of other items. As an illustration, table 1 displays empirically relevant items for selected NASDAQ companies (i.e. the largest three in terms of book value), taken from their fiscal 1999 filings with the Securities and Exchange Commission (SEC). These items can be classified into two groups. The first group can be seen as adjustments to dividends $D_{t}$. Items falling into the second group augment stated earnings $X_{t}$.

First, consider items representing dividend substitutes. For example, a stock repurchase program works like an additional dividend while the issuance of new stock may be seen as a negative dividend. ${ }^{13}$ In order to obtain the total payment stream to shareholders, period t's dividend has to be corrected for capital outflows to shareholders $\left(C O_{t}\right)$ as well as capital inflows to the firm $\left(C I_{t}\right)$. In the below given extended CSR, any financing activity which leads to an increase of equity is captured by $C I_{t}$. This includes the issuance of new common stock in a secondary public offering as

\footnotetext{
${ }^{13}$ However, as known from the Modigliani and Miller theorem, the value of the firm is solely affected by investment activities. For example, a stock split or a stock dividend increases the number of shares, but not the total value of outstanding shares. In contrast, the issuance of new stock increases market capitalization, but if issued at fair price, old shareholders' wealth is not impaired.
} 
well as treasury stock sold in the market. ${ }^{14}$ The same line of reasoning leads to an inclusion of a stock repurchase or the purchase of treasury stock into $C O_{t}$.

Table 1: Items affecting the clean surplus relation - largest 3 NASDAQ companies

\begin{tabular}{|c|c|c|c|c|c|c|c|c|c|c|}
\hline & $\begin{array}{r}\text { Total } \\
\text { Bal }\end{array}$ & $\begin{array}{l}\text { Equity } \\
\text { ance }\end{array}$ & \multirow{2}{*}{\multicolumn{2}{|c|}{$\begin{array}{c}\text { Capital } \\
\text { outflows inflows } \\
\text { to stake- to the } \\
\text { holders } \quad \text { firm }\end{array}$}} & \multirow{3}{*}{$\begin{array}{l}\text { Divi- } \\
\text { dends } \\
-D_{t}\end{array}$} & \multirow{3}{*}{$\begin{array}{c}\text { Tax } \\
\text { bene- } \\
\text { fit } \\
T B_{t}\end{array}$} & \multirow{3}{*}{$\begin{array}{c}\text { Other } \\
\text { items } \\
O I_{t}\end{array}$} & \multirow{3}{*}{$\begin{array}{c}\text { Stated } \\
\text { net } \\
\text { income } \\
\text { APB } \\
X_{t}^{a p b}\end{array}$} & \multirow{2}{*}{\multicolumn{2}{|c|}{$\begin{array}{l}\text { Deviation from } \\
\text { the standard CSR } \\
\text { w/o adj. with adj. } \\
\text { for capital for capital } \\
\text { flows flows }\end{array}$}} \\
\hline & $\begin{array}{l}\text { Begin } \\
\text { of FY }\end{array}$ & $\begin{array}{l}\text { End } \\
\text { of FY }\end{array}$ & & & & & & & & \\
\hline & $B_{t-1}$ & $B_{t}$ & $-C O_{t}$ & $C I_{t}$ & & & & & & \\
\hline WCOM & 45,241 & 51,238 & $\begin{array}{r}0 \\
(0.0 \%)\end{array}$ & $\begin{array}{l}1,115 \\
(2.5 \%)\end{array}$ & $\begin{array}{r}-72 \\
(-0.2 \%)\end{array}$ & $\begin{array}{r}820 \\
(1.8 \%)\end{array}$ & $\begin{array}{r}121 \\
(0.3 \%)\end{array}$ & $\begin{array}{l}4,013 \\
(8.9 \%)\end{array}$ & $\begin{array}{l}-2,056 \\
(-4.5 \%)\end{array}$ & $\begin{array}{c}-941 \\
(-2.1 \%)\end{array}$ \\
\hline INTC & 23,377 & 32,535 & $\begin{array}{r}-4,612 \\
(-19.7 \%)\end{array}$ & $\begin{array}{r}3,128 \\
(13.4 \%)\end{array}$ & $\begin{array}{r}-366 \\
(-1.6 \%)\end{array}$ & $\begin{array}{r}506 \\
(2.2 \%)\end{array}$ & $\begin{array}{r}3,188 \\
(13.6 \%)\end{array}$ & $\begin{array}{r}7,314 \\
(31.3 \%)\end{array}$ & $\begin{array}{r}-2,210 \\
(-9.5 \%)\end{array}$ & $\begin{array}{r}-3,694 \\
(-15.8 \%)\end{array}$ \\
\hline MSFT & 16,627 & 28,438 & $\begin{array}{r}-2,950 \\
(-17.7 \%)\end{array}$ & $\begin{array}{r}3,104 \\
(18.7 \%)\end{array}$ & $\begin{array}{r}-28 \\
(-0.2 \%)\end{array}$ & $\begin{array}{r}3,107 \\
(18.7 \%)\end{array}$ & $\begin{array}{l}1,121 \\
(6.7 \%)\end{array}$ & $\begin{array}{r}7,785 \\
(46.8 \%)\end{array}$ & $\begin{array}{r}-4,054 \\
(-24.4 \%)\end{array}$ & $\begin{array}{l}-3,900 \\
(-23.5 \%)\end{array}$ \\
\hline
\end{tabular}

Displayed are items in the shareholders' equity statement for fiscal 1999, for selected companies out of NASDAQ 100 index (in millions of US \$). The largest three companies in terms of book value of equity are given, i.e. Worldcom (WCOM), Intel (INTC), and Microsoft (MSFT). The first column $\left(B_{t-1}\right)$ displays the total book value of equity at the beginning of a financial year, the second column displays the end of period book value, $B_{t}$. In addition, capital outflows to stakeholders $\left(C O_{t}\right)$, capital inflows to the firm $\left(C I_{t}\right)$, dividends $\left(D_{t}\right)$, tax benefits $\left(T B_{t}\right)$, all other items affecting the book value of equity but not earnings $\left(O I_{t}\right)$, and stated earnings $\left(X_{t}^{a p b}\right)$ are given. Deviations from the CSR are reported in the last two columns, first, without adjusting for capital flows $\left(B_{t-1}-D_{t}+X_{t}^{a p b}-B_{t}\right)$, and second, after adjusting for capital flows $\left(B_{t-1}-C O_{t}+C I_{t}-D_{t}+X_{t}^{a p b}-B_{t}\right)$. In brackets, these figures are given as a percentage of $B_{t-1}$. All figures are derived from the companies' filings with the SEC.

In addition to these common and obvious financing activities, stock-based compensation includes capital inflows to the firm as well. Although they represent an injection of new funds, these offerings are not public since participation is restricted

\footnotetext{
${ }^{14}$ Note that a stock split as well as a stock dividend does not lead to a cash flow, and thus is not included here.
} 
to (selected) employees. Consider a company that grants employee options. If an option is exercised, the option holder receives a share. This may be newly issued stock, or treasury stock which the company has bought back previously in the market. In return, the company receives the strike price. Note that the net capital inflow would have been the same if the company had sold a new share in the market and settled the option in cash. In both cases, the net capital inflow to the firm arising from the exercise is equal to the strike price. Hence, this amount will be captured by $C I_{t}$. If the company does not want to increase the number of outstanding shares by issuing new stocks, it has to buy back the necessary number of shares in the market, either at exercise or previously. ${ }^{15}$ Therefore such a transaction will be treated in the same way as a regular stock repurchase, and thus goes into $C O_{t}{ }^{16}$

All of the above discussed activities associated with stock-based compensation can be classified as financing activities. Since they affect the distributions to current and future shareholders they have to be included into the first group, i.e. dividend substitutes. As can be seen from table 1, these items can lead to substantial distortions. For example, without adjusting for capital in- and outflows, the CSR for Microsoft's fiscal 1999 is imbalanced by roughly $\$ 4$ billion, or $24 \%$ of its begin-of-period book value. Adjusting for net capital inflows will only slightly reduce this imbalance. In contrast, Worldcom's CSR does almost hold.

\footnotetext{
${ }^{15}$ Whether it does so at the time of grant or at the time of exercise just determines how much the company will loose from this transaction. Buying the shares at grant minimizes the loss given the options will be exercised.

${ }^{16}$ Assuming exercise, the net capital inflow over time will be zero if the company grants at-themoney options (i.e. with a strike price equal to the current market price) and at the same time buys these shares in the market. While it has to pay the current stock price in $t_{1}\left(C O_{t_{1}}\right)$, it will get back exactly this amount $\left(C I_{t_{2}}\right)$ in $t_{2}$, i.e. at exercise.
} 
The second group of items are associated with income. For example, the tax treatment of employee options can lead to substantial tax benefits which do not directly affect stated earnings. Although the exercise gains employees realize do not have to be recognized as compensation costs in the profit and loss statement to shareholders, the internal revenue code allows a company to deduct this amount from its taxable income in the case of non-qualified stock options or disqualifying disposition of qualified stock option stock. ${ }^{17}$ This results in a tax benefit which is passed through the equity statement but not through the income statement. In order to account for its effect on the book value of equity it is captured by $T B_{t}$. In addition, all other items which can be interpreted as adjustments to stated earnings and not as dividend substitutes are collected in the term $O I_{t}$. Again, these items affect the book value of equity but do not pass through the profit and loss statement. Basically, these are 'unrealized gains (losses) on investments' and 'foreign currency translation adjustments' which are usually included in the so-called 'other comprehensive income'.

Considering the aforementioned items separately, an extended version of the clean surplus relation (in terms of stated earnings) may be written as

$$
B_{t}=B_{t-1}+X_{t}^{a p b}-D_{t}+C I_{t}-C O_{t}+O I_{t}+T B_{t}
$$

To emphasize that companies commonly apply APB 25, stated earnings are denoted by $X^{a p b}$. Substituting the difference in book values, $\Delta B_{t}=B_{t}-B_{t-1}$, as well as the net capital outflows to shareholders, $N C O_{t}=C O_{t}-C I_{t}$, equation (1) can be rewritten as

$$
\Delta B_{t}=X_{t}^{a p b}-D_{t}-N C O_{t}+O I_{t}+T B_{t}
$$

\footnotetext{
${ }^{17}$ See, for example, Carbery and Weeden (2000).
} 
Assuming that the payment stream to shareholders is completely described by the dividend stream, the fair value of an investment in stocks is given by the well-known dividend discount model. Obviously, in the presence of the aforementioned dividend substitutes (i.e. $N C O_{t} \neq 0$ ) the net distributions to shareholders $D^{\prime}{ }_{t}$ have to be considered instead, where $D_{t}^{\prime}=D_{t}+N C O_{t}$. Then, the present value of the total payment stream is simply given by

$$
V_{t}\left(D^{\prime}\right)=\sum_{\tau=1}^{\infty} \frac{E_{t}\left[D_{t+\tau}^{\prime}\right]}{(1+r)^{\tau}}
$$

where $E_{t}[\cdot]$ denotes conditional expectation given the information at time $t$. In order to keep things simple, risk aversion as well as time varying interest rates are ignored here. ${ }^{18}$ Rewriting the extended clean surplus relationship (2) in terms of net distributions $\left(D_{t}+N C I_{t}=-\Delta B_{t}+X_{t}^{a p b}+O I_{t}+T B_{t}\right)$ and inserting into (3) yields ${ }^{19}$

$$
V_{t}\left(D^{\prime}\right)=\sum_{\tau=1}^{\infty} \frac{E_{t}\left[-\Delta B_{t+\tau}+X_{t+\tau}^{a p b}+O I_{t+\tau}+T B_{t+\tau}\right]}{(1+r)^{\tau}}
$$

Thus, equation (4) gives the present value of future distributions to shareholders. $V_{t}\left(D^{\prime}\right)$ represents the fair value of common stocks attributable to current shareholders only under the assumption that all future claimants have to pay the fair value for their stake in this payment stream. Note that this is not the case with stock-based compensation since employees receive stocks at a discount or get stock options without paying their fair value. The problem arises from the fact that APB 25 does not require to charge the costs of these programs to stated earnings. Thus, based on stated earnings the valuation equation (4) fails to account for the employees' stake in future distributions. Therefore, in the following section equation (4) is

\footnotetext{
${ }^{18}$ Assuming the standard clean surplus relation holds, Feltham and Ohlson (1999) show that the standard residual income valuation model (e.g. Feltham and Ohlson 1995) is easily extended to incorporate risk adjustments and time varying interest rates.

${ }^{19}$ That the dividend discount model may be written in terms of accounting data is well known. See, for example, Edwards and Bell (1961) or Peasnell (1981).
} 
developed further in order to explicitly account for the value impact of stock-based compensation.

\section{Residual income valuation in the presence of stock-based compensation}

Earnings compliant with SFAS 123 are denoted by $X_{t}^{s f a s}$. Then, the additionally recognized compensation by applying SFAS 123 instead of APB 25 is captured by the difference $A R_{t}^{s f a s}=X_{t}^{a p b}-X_{t}^{s f a s}$. Substituting $X_{t}^{a p b}=X_{t}^{s f a s}+A R_{t}^{s f a s}$ into equation (4) and rearranging yields

$$
V_{t}\left(D^{\prime}\right)=\sum_{\tau=1}^{\infty} \frac{E_{t}\left[-\Delta B_{t+\tau}+X_{t+\tau}^{s f a s}+O I_{t+\tau}+T B_{t+\tau}\right]}{(1+r)^{\tau}}+\sum_{\tau=1}^{\infty} \frac{E_{t}\left[A R_{t+\tau}^{s f a s}\right]}{(1+r)^{\tau}}
$$

In the presence of stock-based compensation, the value $V_{t}\left(D^{\prime}\right)$ must be shared among three groups of stakeholders: anyone who holds stocks at time $t,{ }^{20}$ employees who already hold options at time $t$, and employees who will be given stock options or employee stock in periods after time $t .{ }^{21}$ The first term on the right hand side of equation (5) represents the total present value of outstanding stocks, $V_{t}\left(S^{o}\right)$, and of already outstanding options, $V_{t}\left(O^{o}\right)$ :

$$
V_{t}\left(S^{o}\right)+V_{t}\left(O^{o}\right)=\sum_{\tau=1}^{\infty} \frac{E_{t}\left[-\Delta B_{t+\tau}+X_{t+\tau}^{s f a s}+O I_{t+\tau}+T B_{t+\tau}\right]}{(1+r)^{\tau}}
$$

Hence, equation (6) captures all relevant accounting items describing the present value of payments to holders of already outstanding shares and options. The left

\footnotetext{
${ }^{20}$ This includes employees who have already received stocks in connection with stock purchase or stock option plans.

${ }^{21}$ Especially employee stock purchases at a price below the market price have to be considered, too, if no compensation cost is recognized for the discount.
} 
hand side of this equation, i.e. the market value of these securities, can be written as

$$
V_{t}\left(S^{o}\right)+V_{t}\left(O^{o}\right)=N_{t}^{s} P_{t}^{s}+N_{t}^{o} P_{t}^{o}
$$

where $P_{t}^{o}\left(P_{t}^{s}\right)$ denotes the fair value of options (market price of stocks) at time $t$, and $N_{t}^{o}\left(N_{t}^{s}\right)$ the number of outstanding options (stocks). Neglecting stock purchase programs as well as accrual issues, the additionally recognized part of compensation cost in future earnings, $A R^{\text {sfas }}$, will be different from zero only if options (with a non-zero strike price) will be granted to employees after time $t$. The present value of additionally recognized compensation cost applying SFAS 123 is then given by the second right-hand side term in equation (5):

$$
V_{t}(A R)=\sum_{\tau=1}^{\infty} \frac{E_{t}\left[A R_{t+\tau}^{s f a s}\right]}{(1+r)^{\tau}}
$$

This term may be interpreted as the present value of future option grants, $V_{t}\left(O^{f}\right)$, under certain assumptions. Especially, one has to assume that an appropriate option pricing model is applied. ${ }^{22}$ Neglecting effects arising from employee stock purchase programs, in addition, all options have to be granted at-the-money in order that the difference $X^{a p b}-X^{s f a s}$ reflects the total value of employee options. Indeed, US companies grant primarily at-the-money options (see e.g. NCEO 2000). If, for example, in-the-money options are granted the intrinsic value at the grant date has

\footnotetext{
${ }^{22}$ As shown by Acharya et al (2000) among others, CEO options might be more appropriately valued by a model which includes resetting features. For empirical evidence on resetting CEO options see, for example, Brenner et al (2000), or Chance et al (2000). Yermack (1998) presumes that the value of executive options will be underestimated by the regular Black-Scholes model since CEOs are able to influence dividend policy, and in addition, may base their exercise decision on inside information. In contrast, Huddart (1994) claims that the basic Black-Scholes model largely overestimates the value of employee options. An alternative model for employee stock options is presented by Aboody (1996).
} 
to be recognized as compensation cost which reduces both, $X^{a p b}$ and $X^{s f a s}$. In this case, the difference does not capture the total option value at grant, and the total present value of future options grants $V_{t}\left(O^{f}\right)$ is larger than $V_{t}(A R)$. Nevertheless, the difference $V_{t}\left(O^{f}\right)-V_{t}(A R)$ does not show up in eq (6) since it is treated like a regular wage component which reduces stated earnings.

With $E_{t}\left[b_{t+n}\right] /(1+r)^{n} \rightarrow 0$ for $n \rightarrow \infty$, equation (6) can be rewritten as

$$
V_{t}\left(S^{o}\right)+V_{t}\left(O^{o}\right)=B_{t}+\sum_{\tau=1}^{\infty} \frac{E_{t}\left[-r B_{t+\tau-1}+X_{t+\tau}^{s f a s}+O I_{t+\tau}+T B_{t+\tau}\right]}{(1+r)^{\tau}}
$$

Substituting $X_{t}^{a a}=+X_{t+\tau}^{s f a s}+O I_{t+\tau}+T B_{t+\tau}-r B_{t-1}$, one obtains an equation similar to the standard residual income valuation model:

$$
V_{t}\left(S^{o}\right)+V_{t}\left(O^{o}\right)=B_{t}+\sum_{\tau=1}^{\infty} \frac{E_{t}\left[X_{t+\tau}^{a a}\right]}{(1+r)^{\tau}}
$$

As a reference to Ohlson (1992), $X_{t}^{a a}$ may be termed augmented abnormal earnings. Hence, on the basis of simple no-arbitrage arguments one arrives at a residual income valuation model in the spirit of Ohlson (1995) which accounts for the effects of employee stock and option programs. In contrast to Ohlson, however, the resulting present value does not represent the value of stocks alone, instead this value has to be shared between holders of stocks and options.

\section{Conditioning on currently known information}

Valuing stocks on the basis of equation (8) is complicated by the fact that it involves earnings forecasts with infinite horizon. Although in general, analysts' estimates may be used, such forecasts are rarely available for a horizon beyond three to five years. 
An intriguing approach to incorporate long-term forecasts based on currently available information is introduced by Ohlson (1995). He assumes a vector autoregressive process in order to jointly model the time series properties of abnormal earnings $X_{t}^{a}$ as well as related other information $\nu_{t}$, e.g. analysts' estimates. Conditional on the information available at time $t$, the solution for the value of equity is found in terms of the predictable components of the system. This is intuitively appealing, since it exploits predictability in abnormal earnings as well as other value relevant information which, for example, may stem from analysts.

Ohlson's residual income valuation model builds on stated earnings because he assumes that earnings are attributable to shareholders only and that the standard CSR holds. Then, abnormal earnings represent the part of earnings exceeding the required capital charge. However, as delineated above, both assumptions rarely hold since under current accounting rules various items by-pass the profit and loss statement. Thus, ordinary abnormal earnings defined on the basis of stated earnings do not correctly measure the creation of shareholders' wealth. The above defined augmented abnormal earnings were derived in order to overcome these deficiencies. Since augmented abnormal earnings do precisely reflect the part of earnings exceeding the required capital charge which determines the creation of wealth, they fit exactly into the Ohlson dynamic.

We assume a earnings dynamic corresponding to one used by Ohlson (1995). Replacing $X_{t}^{a}$ by $X_{t}^{a a}$, Ohlson's driftless vector autoregressive (VAR) process of order one can be written as

$$
\begin{aligned}
X_{t}^{a a} & =\omega X_{t-1}^{a a}+\nu_{t-1}+\varepsilon_{1, t} \\
\nu_{t} & =\gamma \nu_{t-1}+\varepsilon_{2, t}
\end{aligned}
$$


where $\varepsilon_{i, t}, i=1,2$, denote i.i.d. error terms and $|\omega|<1$ as well as $|\gamma|<1$ are autoregressive parameters. Deriving conditional expectations of abnormal earnings and inserting into the present value equation (8) one obtains an expression similar to Ohlson (1995), i.e.

$$
V_{t}\left(S^{o}\right)+V_{t}\left(O^{o}\right)=B_{t}+\alpha_{1} X_{i, t}^{a a}+\alpha_{2} \nu_{t}
$$

with

$$
\begin{aligned}
\alpha_{1} & =\frac{1+r}{\omega-1-r} \\
\alpha_{2} & =\frac{1+r}{(1+r-\omega)(1+r-\gamma)}
\end{aligned}
$$

Equation (9) shows that Ohlson's residual income residual income valuation formula holds when a correct measure for wealth creation $\left(X^{a a}\right)$ is used and the resulting present value is corrected for the stake of option holders.

Note that the specific dynamics assumed by Ohlson (1995) and Feltham and Ohlson (1999) can be easily modified in order to test for more appropriate forecasting specifications. For example, Bar-Yosef et al (1996) scrutinize the assumed dynamics and analyze alternative specifications of VAR processes. ${ }^{23}$ Whether or not the Ohlson dynamic is best suited to exploit predictability in (abnormal) earnings is an empirical question and therefore not pursued here.

\section{Conclusions}

Residual income valuation depends on the clean surplus relation. As pointed out by Ohlson (2000), among others, the standard clean surplus relation rarely holds.

\footnotetext{
${ }^{23}$ Based on the Akaike information criterion, they conclude that a lag structure of two might be more appropriate. However, the optimal lag structure seems to depend on the variable to be forecasted.
} 
Furthermore, given the current accounting practice, a residual income valuation model based on stated earnings overestimates the fair value of outstanding stocks since it does not account for the cost of stock option programs. Therefore, the paper generalizes the standard clean surplus relation and presents an extension to the seminal Ohlson model. Based on straightforward value additivity arguments simple analytical solutions for the fair value of stocks are derived removing the aforementioned distortions which hinder the applicability of the standard valuation approach. As a by-product, it follows immediately from our model that earnings compliant with SFAS 123 are more appropriate than earnings applying APB 25 to derive the value of outstanding stocks.

Moreover, the paper devises a viable alternative model for testing valuation issues in connection with accounting data. In particular, the model allows to investigate the issue of stock-based compensation. Thus far, this issue has been addressed on the basis of more or less ad-hoc regression specifications connected only loosely to residual income valuation. In contrast, the presented model permits to derive straightforward tests whether investors take into account the value of outstanding and newly granted employee stock options.

\section{Acknowledgements}

For invaluable discussions we are indebted to Günter Franke, Christian Gaber, Joachim Inkmann, Mathias Külpmann, Jan P. Krahnen, and Winfried Pohlmeier. We have also strongly benefited from comments by Axel Adam-Müller, Nikolaus Hautsch, Markus Hetzer, Frank Gerhard, Stefan Klotz, Erik Lehmann, May H. Lo, Raimond Maurer, Lisa Meulbroeck, Harris Schlesinger, Michael Schröder, Piet Sercu, Christina J. Sinn, and participants of the 4th Conference of the Swiss Society for Financial Market Research in Bern and the 18th Annual Meeting of the French 
Finance Association in Namur. Earlier versions of this paper have been presented at the Universities of Frankfurt and Konstanz and the Centre for European Economic Research in Mannheim. All remaining errors are our sole responsibility. Dieter Hess appreciates financial support by the Deutsche Forschungsgemeinschaft (DFG, project HE 3180/1). In addition, we are both grateful for financial support by the Center of Finance and Econometrics (CoFE) and the Centre for European Economic Research (ZEW).

\section{Appendix: Multivariate earnings dynamics - Proof of equa- tion (9)}

Define a two-element vector $\mathbf{z}_{t}=\left[X_{t}^{a}, \nu_{t}\right]^{\prime}$ consisting of abnormal earnings $X_{t}^{a}$ and of any other information $\nu_{t} . \mathbf{z}^{\prime}$ denotes the transpose of $\mathbf{z}$. Ohlson assumes that $\mathbf{z}_{t}$ follows a vector autoregressive (VAR) process of order one with zero drift:

$$
\mathbf{z}_{t}=\mathbf{C} \mathbf{z}_{t-1}+\mathbf{e}_{t}
$$

where $\mathbf{e}_{t}$ denotes a $(2 \times 1)$ vector of i.i.d. residuals, i.e. $\mathbf{e}_{t}=\left[\varepsilon_{1, t}, \varepsilon_{2, t}\right]^{\prime}$, and $\mathbf{C}$ a $(2 \times 2)$ coefficient matrix in which the off-diagonal elements are restricted to 1 and 0 :

$$
\mathbf{C}=\left[\begin{array}{ll}
\omega & 1 \\
0 & \gamma
\end{array}\right]
$$

$\omega$ and $\gamma$, are autoregressive parameters. Furthermore, abnormal earnings $X_{t}^{a}$ are given by

$$
X_{t}^{a}=\mathbf{a}^{\prime} \mathbf{z}_{t}
$$

where a specifies the relation between $\mathbf{z}_{t}$ and abnormal earnings $X_{t}^{a}$. In the Ohlson model this is simply $\mathbf{a}=[1,0]^{\prime}$.

Conditional expectations are given by

$$
E_{t}\left[\mathbf{z}_{t+s}\right]=\mathbf{C}^{s} \mathbf{z}_{t}
$$

where $\mathbf{C}^{s}$ is the matrix product $\prod_{i=1}^{s} \mathbf{C}$. Furthermore, define $R=1+r$. Substituting conditional expectations into Ohlson's valuation equation

$$
V_{t}=B_{t}+\sum_{s=1}^{\infty} R^{-s} E_{t}\left[X_{t+s}^{a}\right]
$$


yields

$$
V_{t}-B_{t}=\sum_{s=1}^{\infty} R^{-s} \mathbf{a}^{\prime} \mathbf{C}^{s} \mathbf{z}_{t}=\mathbf{a}^{\prime}\left(\sum_{s=1}^{\infty} R^{-s} \mathbf{C}^{s}\right) \mathbf{z}_{t}
$$

With $\mathbf{D}=R^{-1} \mathbf{C}$ the well-known model of Ohlson (1995) is obtained as

$$
V_{t}-B_{t}=\mathbf{a}^{\prime} \mathbf{D}[\mathbf{I}-\mathbf{D}]^{-1} \mathbf{z}_{t}
$$

where $\mathbf{I}$ is a $(2 \times 2)$ identity matrix. Since

$$
[\mathbf{I}-\mathbf{D}]^{-1}=\left[\begin{array}{cc}
-R /(\omega-R) & R /((\omega-R)(\gamma-R)) \\
0 & -R /(\omega-R)
\end{array}\right],
$$

eq. (11) can rewritten as

$$
V_{t}=B_{t}+\alpha_{1} X_{i, t}^{a}+\alpha_{2} \nu_{t}
$$

with

$$
\begin{aligned}
\alpha_{1} & =\frac{1+r}{\omega-1-r} \\
\alpha_{2} & =\frac{1+r}{(1+r-\omega)(1+r-\gamma)}
\end{aligned}
$$

Note that our valuation equation (8), i.e.

$$
V_{t}\left(S^{o}\right)+V_{t}\left(O^{o}\right)=B_{t}+\sum_{\tau=1}^{\infty} \frac{E_{t}\left[X_{t+\tau}^{a a}\right]}{(1+r)^{\tau}}
$$

differs slightly from eq. (10). Assuming the same dynamics as Ohlson for augmented abnormal earnings and additional information, i.e. $\mathbf{z}_{t}=\left[X_{t}^{a a}, \nu_{t}\right]^{\prime}$ and inserting conditional expectations into eq. (8) yields eq. (9), i.e

$$
V_{t}\left(S^{o}\right)+V_{t}\left(O^{o}\right)=B_{t}+\alpha_{1} X_{i, t}^{a a}+\alpha_{2} \nu_{t}
$$

with $\alpha_{1}$ and $\alpha_{2}$ as defined above. 


\section{References}

ABoody, D. (1996): "Market Valuation of Employee Stock Options," Journal of Accounting and Economics, 22, 357-91.

Acharya, V. V., K. John, and R. K. Sundaram (2000): "On the optimality of resetting executive stock options," Journal of Financial Economics, 57.

AdAm-Müller, A., And C. Wangler (2001): "Das Positionspapier der Arbeitsgurppe Stock Options des Deutschen Standardisierungsrates," FINANZ BETRIEB, Beilage Kapitalmarktorientierte Rechnungslegung, 1, 1-12.

Anonymous (2001): "Called to account," The Economist, January 27, pp. 15-17.

Bar-Yosef, S., J. L. Callen, and J. Livnat (1996): "Modeling Dividends, Earnings, and Book Value Equity: An Empirical Investigation of the Ohlson Valuation Dynamics," Review of Accounting Studies, 1, 207-224.

Brenner, M., R. K. Sundaram, and D. Yermack (2000): "Altering the terms of executive stock options," Journal of Financial Economics, 57, 103-128.

Callies, C. A., And P. Sareen (2000): "Stock Options Creating Wealth for the Lucky Few," in: Equity Research, February 7, 2000, Credit Swiss First Boston.

Carbery, E., and R. Weeden (2000): "A Primer on Stock Options for Employees," in The Stock Options Book, ed. by National Center of Employee Ownership, NCEO, Oakland, 3rd ed.

Carson, J. (2000): "US Economic Perspectives - Stock Option Study of S\&P 500 Companies," in: Global Economic and Strategic Research, July 14, 2000, UBS Warburg.

Chance, D. M., R. Kumar, and R. B. Todd (2000): "The 'repricing' of executive stock options," Journal of Financial Economics, 57, 129-154.

Core, J. E., and W. R. Guay (2000): "Stock Option Plans for Non-Executive Employees," Discussion paper, SSRN, forthcoming in: Journal of Financial Economics. 
Core, J. E., W. R. Guay, and S. Kothari (2000): "The Economic Dilution of Employee Stock Options: Diluted EPS for Valuation and Financial Reporting," Discussion paper, SSRN.

Dechow, P. M., A. P. Hutton, and R. G. Sloan (1996): "Economic consequences of accounting for stock-based compensation," Journal of Accounting Research, 34, 1-20.

- (1999): "An empirical assessment of the residual income valuation model," Journal of Accounting and Economics, 26, 1-34.

Edwards, E. O., And P. W. Bell (1961): The Theory and Measurement of Business Income. University of California Press.

Feltham, G. A., and J. A. Ohlson (1995): "Valuation and Clean Surplus Accounting for Operating and Financial Activities," Contemporary Accounting Research, 11(2), 689-731.

_ (1999): "Residual Earnings Valuation With Risk and Stochastic Interest Rates," Accounting Review, $74(2), 165-183$.

Franke, G. (2000): "Deutsche Finanzmarktregulierung nach dem Zweiten Weltkrieg zwischen Risikoschutz und Wettbewerbssicherung," Discussion Paper 00-31, Center of Finance and Econometrics, University of Konstanz.

Freeman, G. R., and G. A. Larsen JR. (2000): "The Market's Reaction To The FASB Stock-based Compensation Project," Journal of Applied Business Research, 13(4), 83-91.

Hess, D., AND E. LÜDERs (2000): "Do companies exploit accounting rules for broad-based stock option plans? A case study," Discussion Paper 00-27, Center of Finance and Econometrics, University of Konstanz.

(2001): "Mitarbeiter Optionen steigern den ausgewiesenen Gewin: Eine Studie des NASDAQ 100," FINANZ BETRIEB, Beilage Kapitalmarktorientierte Rechnungslegung, 1, 12-1\%. 
Huddart, S. (1994): "Employee Stock Options," Journal of Accounting and Economics, 18(2), 207-231.

Liang, J. N., And S. A. Sharpe (1999): "Share Repurchases and Employees Stock Options and their Implications for S\&P 500 Share Retirements and Expected Returns," Discussion Paper 59, Federal Reserve Board, Staff Studies.

Liu, J., And J. A. Ohlson (2000): "The Feltham-Ohlson (1995) Model: Empirical Implications," Journal of Accounting, Auditing \& Finance, pp. 321-331.

LüCKE, W. (1955): "Investitionsrechnung auf der Grundlage Ausgaben oder Kosten?," Zeitschrift fü handelswissenschaftliche Forschung, 7, 310-324.

NCEO (2000): Current Practices in Stock Option Plan Design, revised and expanded edition. National Center for Employee Owernership, Oakland, CA.

Ohlson, J. A. (1992): "The theory of value and earnings, and an introduction to the Ball-Brown analysis," Contemporary Accounting Research, 8, 1-19.

- (1995): "Earnings, Book Values, and Dividends in Equity Valuation," Contemporary Accounting Research, 11(2), 661-68\%.

(2000): "Residual Income Valuation: The Problems," Discussion paper, New York University, March 2000.

Peasnell, K. (1981): "On Capital Budgeting and Income Measurement," Abacus, pp. $361-381$.

REes, L., And D. Stott (1998): “The Value-Relevance of Stock-Based Employee Compensation Disclosures," Discussion paper, Washington State University, December 1998.

Sougiannis, T., And T. Yaekura (2000): "The Accuracy and Bias of Equity Values Inferred from Analysts' Earnings Forecasts," Discussion paper, University of Illinois at Urbana-Champaign.

Street, D. L., D. R. Fordham, and A. Wayland (1997): "Stock Options as a Form of Ccompensation for American Executives: Impact on Accounting Rules of 
Themes and Arguments Reported in Newspapers and Business Magazines, 19751993," Critical Perspectives on Accounting, 8(3), 211-42.

TOWERs PERrin (2000): "The Cost of Management Incentives: How Much Cash and Stock Do Companies Use?," CompScan Report, Towers Perrin, Valhalla, NY.

Tse, S. Y., And R. A. YaAnsah (1999): "An Analysis of Historical and FutureOriented Information in Accounting-Based Security Valuation Models," Contemporary Accounting Research, 16(2), 347-380.

Yermack, D. (1998): "Companies' Modest Claims about the Value of CEO Stock Option Awards," Review of Quantitative Finance and Accounting, 10, 207-26. 